University of Nebraska - Lincoln

DigitalCommons@University of Nebraska - Lincoln

2012

Snow cover, snowmelt timing and stream power in the Wind River Range, Wyoming

Dorothy K. Hall

NASA Goddard Space Flight Center

James L. Foster

NASA Goddard Space Flight Center

Nicolo E. DiGirolamo

SSAl, Lanham, MD

George A. Riggs

SSAl, Lanham, MD

Follow this and additional works at: https://digitalcommons.unl.edu/nasapub

Part of the Physical Sciences and Mathematics Commons

Hall, Dorothy K.; Foster, James L.; DiGirolamo, Nicolo E.; and Riggs, George A., "Snow cover, snowmelt timing and stream power in the Wind River Range, Wyoming" (2012). NASA Publications. 58.

https://digitalcommons.unl.edu/nasapub/58

This Article is brought to you for free and open access by the National Aeronautics and Space Administration at DigitalCommons@University of Nebraska - Lincoln. It has been accepted for inclusion in NASA Publications by an authorized administrator of DigitalCommons@University of Nebraska - Lincoln. 


\title{
Snow cover, snowmelt timing and stream power in the Wind River Range, Wyoming
}

\author{
Dorothy K. Hall ${ }^{\text {a, }}$, James L. Foster ${ }^{\text {a }}$, Nicolo E. DiGirolamo ${ }^{b}$, George A. Riggs ${ }^{b}$ \\ a Laboratory for Hydrospheric and Biospheric Processes, NASA Goddard Space Flight Center, Greenbelt, MD 20771, USA \\ b SSAI, Lanham, MD 20706, USA
}

\section{A R T I C L E I N F O}

\section{Article history:}

Received 7 April 2010

Received in revised form 22 September 2010

Accepted 30 November 2010

Available online 27 March 2011

\section{Keywords:}

Wind River Range

MODIS

Seasonal snow cover

Streamflow runoff

\begin{abstract}
A B S T R A C T
Earlier onset of springtime weather, including earlier snowmelt, has been documented in the western United States over at least the last 50 years. Because the majority $(>70 \%)$ of the water supply in the western U.S. comes from snowmelt, analysis of the declining spring snowpack (and shrinking glaciers) has important implications for the management of streamflow. The amount of water in a snowpack influences stream discharge which can also influence erosion and sediment transport by changing stream power, or the rate at which a stream can do work, such as move sediment and erode the stream bed. The focus of this work is the Wind River Range (WRR) in west-central Wyoming. Ten years of Moderate-Resolution Imaging Spectroradiometer (MODIS) snow-cover, cloud-gap-filled (CGF) map products and 30 years of discharge and meteorological station data are studied. Streamflow data from streams in WRR drainage basins show lower annual discharge and earlier snowmelt in the decade of the 2000s than in the previous three decades, though no trend of either lower streamflow or earlier snowmelt was observed within the decade of the 2000s. Results show a statistically-significant trend at the 95\% confidence level (or higher) of increasing weekly maximum air temperature (for three out of the five meteorological stations studied) in the decade of the 1970s, and also for the 40-year study period as a whole. The extent of snow-cover (percent of basin covered) derived from the lowest elevation zone (2500-3000 m) of the WRR, using MODIS CGF snow-cover maps, is strongly correlated with maximum monthly discharge on 30 April, where Spearman's Rank correlation, $\mathrm{r}_{\mathrm{s}},=0.89$ for the decade of the 2000s. We also investigated stream power for Bull Lake Creek above Bull Lake; and found a trend (significant at the $90 \%$ confidence level) toward reduced stream power from 1970 to 2009 . Observed changes in streamflow and stream power may be related to increasing weekly maximum air temperature measured during the 40-year study period, possibly contributing to a reduction in snow cover. In addition, the strong relationship between percent of basin that was snow covered, and maximum monthly streamflow indicates that MODIS snow-cover maps are useful for predicting streamflow, and can be used to improve management of water resources in the drought-prone western United States.
\end{abstract}

Published by Elsevier B.V.

\section{Introduction and background}

Earlier onset of spring-like weather has been documented in the western United States since at least the late 1970s; the warm episodes are related to larger-scale atmospheric conditions across North America and the North Pacific (Cayan et al., 2001; Mote, 2003; Mote et al., 2005). In addition, most of the glaciers throughout western North America have generally been losing mass since the Little Ice Age ended in the mid-to-late 1800s (Cheesbrough et al., 2009; Moore et al., 2009; PDX, 2010a). Mean annual temperatures over northwestern North America increased by $\sim 1-2{ }^{\circ} \mathrm{C}$ (Karl et al., 1993; Dettinger and Cayan, 1995) from the 1940 s to the early 1990 s, with perhaps a greater increase from the mid-1960s to the early 1990s (Naftz et al., 2002).

\footnotetext{
* Corresponding author.

E-mail address: dorothy.k.hall@nasa.gov (D.K. Hall).
}

In many high-elevation streams in the western U.S. a reduction has occurred in the portion of annual stream discharge occurring during spring and early summer, that fraction of the streamflow attributable to spring snowmelt (see for example, Dettinger and Cayan, 1995; Cayan et al., 2001). The fraction of annual streamflow that runs off during late spring and summer has declined by $10-25 \%$ since the 1950 s because of warmer winter and spring weather (Cayan et al., 2001), and snowmelt runoff arrives 1-3 weeks earlier in many mountain basins in the western U.S. (Stewart et al., 2005; Lundquist et al., 2009). Warmer air temperatures also may be associated with less total extent of snow cover (see for example, Foster et al., 1983; Groisman et al., 1994; Cohen and Fletcher, 2007) especially at the lower elevations. In much of the western U.S., and specifically in western Wyoming where the Wind River Range (WRR) is located, the date of spring snowmelt onset is earlier by up to or greater than 20 days as compared to the mid-20th Century (USGS, 2005). Because the majority of the water supply in the western U.S. ( $>70 \%$ ) comes from snowmelt (and to a much-lesser extent, from glacier melt), analysis of the snowpack and glacier extent 
has important implications for the management of streamflow (Mote, 2003; USGS, 2005; Westerling et al., 2006).

In addition to the influence of the amount of snow and the timing of melt on water resources, stream power is also affected by the mountain snowpack. Stream power influences the amount and size of sediment transport and, thus, the ability of the stream to erode the stream bed. Stream power (Bagnold, 1977; Ferguson, 2005) is the rate of energy dissipation against the bed and banks of a river or stream. [Effective discharge is another measure of interest but was not investigated in this study. Computations of effective discharge can provide a basis for comparing the geomorphic work of streams in different watersheds (Crowder and Knapp, 2005)].

The objective of this work is to investigate the relationship between air temperature and snow cover in the WRR from 2000 to 2009, and to address the influence of changing conditions of the snowpack on the amount and timing of snowmelt, and stream power. We use 10 years of Moderate-Resolution Imaging Spectroradiometer (MODIS) snow-cover maps of the WRR along with ancillary data (a digitalelevation model (DEM), streamflow data and air-temperature data). Our focus is on the lowest elevations of the WRR (2500-3000 m) because the lower elevations are the most vulnerable to changes in the timing of snowmelt (e.g., Mote, 2003).

\section{Geographic setting}

The Wind River Range spans $210 \mathrm{~km}$ along the Continental Divide in western Wyoming, with a maximum elevation of $4205 \mathrm{~m}$ (Fig. 1). Mean-annual precipitation is $100-130 \mathrm{~cm}$ over most of the WRR, rising to $>150 \mathrm{~cm}$ close to the crest line. In the highest areas of the
WRR average annual snowfall is roughly $500 \mathrm{~cm}$ (Pochop et al., 1989). Most of the precipitation falls as snow and results when Pacific air masses are lifted over the mountains (orographic precipitation), with the southwestern (windward) flanks receiving more precipitation than the northeastern (leeward) flanks (Oswald and Wohl, 2008). A snowpack typically forms in October and melts between late March and mid-June. Approximately two-thirds of the precipitation runs off as streamflow (Foster and Hall, 1981).

The WRR contains 25 of the 38 named glaciers in Wyoming, including Gannett Glacier $\left(3.3 \mathrm{~km}^{2}\right)$ which is the largest glacier in the continental U.S. outside of Washington State (PDX, 2010b). Most of the glaciers located in the WRR are north or east facing and are on the eastern slope of the Continental Divide (Meier, 1950). Cheesbrough et al. (2009) found that glaciers decreased in area an average of $25 \%$ between 1985 and 2005 .

Meltwater runoff from the snow and glaciers flows into two separate drainage systems, separated by the Continental Divide (see location of the Continental Divide in Fig. 1). Runoff on the western slopes flows into the Colorado River Basin which then flows into the Gulf of California, whereas runoff on the eastern slopes flows into the Missouri River Basin and then into the Gulf of Mexico (Pochop et al., 1990).

\section{Data and methodology}

\subsection{Moderate-Resolution Imaging Spectroradiometer (MODIS) snow- cover maps}

Daily snow-cover maps are produced, cloud-cover permitting, from MODIS at a spatial resolution of 500 m (Riggs et al., 2006; Hall

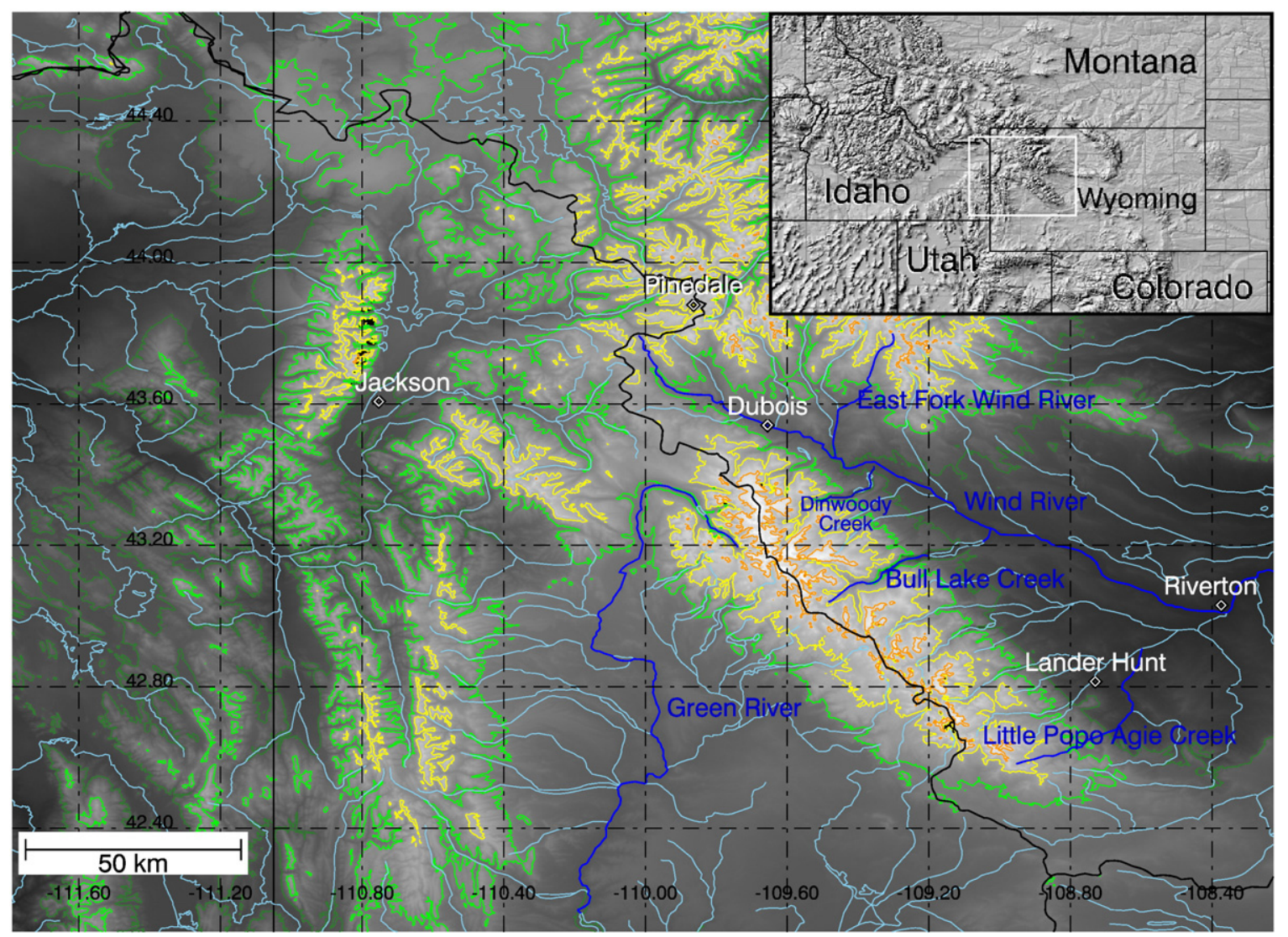

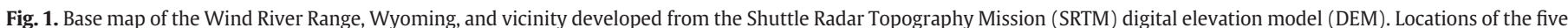

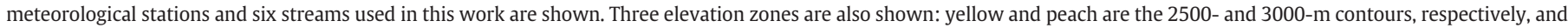

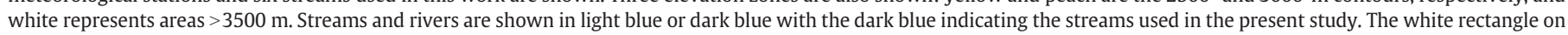
the image (inset) shows the location of the larger image. Locations of streams and the Continental Divide (black line) were obtained from the U.S. Geological Survey. 
and Riggs, 2007). The MODIS instrument was first launched on the Terra spacecraft in December 1999 and began producing data in early 2000. A second MODIS was launched on the Aqua spacecraft in May of 2002. Data used in this study are from Version 5 of Terra MODIS standard snow-cover maps. MODIS is a 36-channel instrument from which standard products (MODIS, 2010a) are produced in an automated production environment, including validated daily, global snow-cover maps, at spatial resolutions of $500 \mathrm{~m}$ and $0.05^{\circ}$ (MODIS, $2010 \mathrm{~b}$ ). The products provide fractional-snow cover (FSC) and snow albedo (Hall et al., 2002; Klein and Stroeve, 2002; Salomonson and Appel, 2004; Riggs et al., 2006; Hall and Riggs, 2007). There is also a new (not-yet-standard) product called the cloud-gap-filled (CGF) MODIS snow-cover map product that uses a gap-filling algorithm to create cloud-free daily snow-cover maps (Hall et al., 2010).

MODIS-derived snow-cover depletion curves were developed from the 500-m resolution standard MODIS snow-cover products at three elevation ranges in the WRR for 10 years, using the MODIS standard FSC product, MOD10A1. For this work, a pixel was considered to be snow covered if the FSC was $\geq 20 \%$. Using MOD10A1, cloudcover was restricting our view of the entire WRR on roughly half of the days during the critical snowmelt season, so we decided to use the CGF product, hereafter to be referred to as MOD10A1 CGF or MODIS CGF snow-cover maps. Using MOD10A1 CGF, all days provided opportunities to measure the extent of snow cover when the MODIS instrument was operating. We measured snow cover in the WRR using MODIS CGF snow-cover maps from 20 or 21 March to 30 or 31 July (days 80-212) from 2000 to 2009.

\subsection{MODIS cloud-gap-filled (CGF) snow-cover maps}

To develop the MODIS CGF snow-cover map product, gaps caused by cloud cover in the MOD10A1 snow-cover extent maps are filled using the last "clear" observation of the surface, for each grid cell. If cloud cover is shown in a grid cell on the day on which the map is produced, the last clear observation for that grid cell is retained and used as the observation for that day.

The MODIS CGF snow-cover map is made from the standard MOD10A1 product using snow-cover fractions from 20 to $100 \%$. Cloud-cover data from MOD10A1 are used to determine if a grid cell is cloud obscured for each day. If cloud cover is $\geq 80 \%$ then the cell is classified as cloud covered. If a grid cell is cloud covered on the image date, the last clear-view observation is retained as the observation for the current day.

Persistence of cloud cover following the last clear observation of the surface causes confidence in the accuracy of the cloud-gap-filled snow map to erode along with age of the last observation. A cloudpersistence count $(\mathrm{CPC})$ is kept for every grid cell and updated each day so that the number of cloudy days preceding the image date is tracked. The snow confidence is calculated as: snow cover minus the CPC. When a clear view is available after one or more cloudy days, the CPC is reset to zero. Thus, a CPC of zero means that the image date was clear. Using the CGF product, the accuracy of the measurement of snow cover in each grid cell on any given day varies depending on cloud conditions (see Hall et al. (2010) for further explanation of this product and its limitations).

\subsection{Ancillary data}

We also used meteorological data from the National Climatic Data Center (NCDC) (NCDC, 2010) for the following five stations: Dubois (elev. 2117 m), Jackson (elev. 1900 m), Lander Hunt (elev. 1703 m), Pinedale (elev. $2187 \mathrm{~m}$ ) and Riverton (elev. $1509 \mathrm{~m}$ ) (see station locations in Fig. 1). Though these stations are below our study area in elevation, they provide useful information and contribute to our understanding of changes occurring in this region.
Additionally, we employed a Shuttle Radar Topography Mission (SRTM) digital-elevation model (DEM) (JPL, 2010). The inherent resolution of the SRTM DEM is $30 \mathrm{~m}$ (1 arc-second) which is a much higher resolution than we needed to undertake most aspects of our study. Therefore, to facilitate its use, we degraded the resolution of the DEM to $300-\mathrm{m}$ using a simple averaging technique to reduce the size of the data files.

Discharge data from gauged streams were acquired from the U.S. Geological Survey (USGS, 2010) for six streams from 1970 to 2009: Bull Lake Creek above Bull Lake $\left(43.18^{\circ} \mathrm{N}, 109.2^{\circ} \mathrm{W}\right.$; station ID 06224000) (no missing data); Dinwoody Creek above Lakes $\left(43^{\circ} 20^{\prime}\right.$ $\mathrm{N}, 109^{\circ} 24^{\prime} \mathrm{W}$; station ID 06221400 ) (data missing from 5 October 1978 to 30 September 1988); East Fork of the Wind River near Dubois

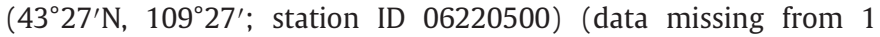
October 1997 to 31 December 2009 as well as from some additional days in late 1985 and 1986, including most days from the snowmelt season in 1986); Green River at Warren Bridge $\left(43^{\circ} 01^{\prime} \mathrm{N}, 110^{\circ} 07^{\prime} \mathrm{W}\right.$; station ID 09188500) (data missing from 1 October 1992 to 30 September 1993); Little Popo Agie River near Lander $\left(42^{\circ} 43^{\prime} \mathrm{N}\right.$, $108^{\circ} 38^{\prime} \mathrm{W}$; station ID 06233000) (data available only from April through October each year from 2000 to 2009); and Wind River near Dubois $\left(43^{\circ} 34^{\prime} \mathrm{N}, 109^{\circ} 45^{\prime} \mathrm{W}\right.$; station ID 06218500 ) (data missing from 1 October 1992 to 30 April 2001). The mean elevation of all of the watersheds is below $3000 \mathrm{~m}$.

\subsection{Methodology}

The daily MOD10A1 CGF snow-cover maps were registered to the SRTM DEM covering the WRR. We divided the WRR Basin into three elevation zones: $2500-3000 \mathrm{~m}, 3000-3500 \mathrm{~m}$ and $>3500 \mathrm{~m}$ (see elevation zones in Fig. 1). We also calculated stream power in the lowest elevation zone of Bull Lake Creek above Bull Lake.

We investigated the relationship between the area of MODISderived snow cover (percent of basin that was snow covered) and streamflow using volume of daily peak streamflow, volume of maximum monthly streamflow and volume of seasonal total streamflow. Daily peak streamflow is the annual maximum mean daily flow determined by selecting the day of maximum mean flow, and using that value (volume) as the maximum mean amount of daily flow for that year. Maximum monthly streamflow is the total discharge (sum of daily mean streamflow volume) that occurs during the month with the highest total discharge for a given year. Seasonal total streamflow is the sum of the daily mean discharge volume for the entire season. Our snowmelt season for the present work extends from 20 or 21 March through 30 or 31 July (days 80-212) each year. To derive the values in Tables 1-3, we first calculate volume of streamflow and then add the volume totals of five of the six streams.

Stream power was calculated for Bull Lake Creek above Bull Lake by determining the slope of the stream channel determined from the SRTM DEM using the full 30-m resolution. Bull Lake Creek above Bull Lake was selected because that stream has a continuous streamflow record from 1970 to 2009.

Once the slope was determined, stream power, $\Omega$, in $\mathrm{kW} \mathrm{m}^{-1}$ was calculated using Eq. (1) (Bagnold, 1977; Bloom, 1991).

$\Omega=\rho g Q S$

where $\rho$ is the density of water $\left(1000 \mathrm{~kg} / \mathrm{m}^{3}\right), g$ is acceleration due to gravity $\left(9.8 \mathrm{~m} / \mathrm{s}^{2}\right), Q$ is hydraulic discharge $\left(\mathrm{m}^{3} / \mathrm{s}\right)$, and $S$ is the channel slope. Then we calculated maximum monthly stream power by selecting the month with the greatest stream power in each year.

\subsection{Statistical methodology}

Spearman's Rank correlation analysis was used to analyze the relationship between the MODIS-derived snow-cover extent, and 
Table 1

Spearman's Rank correlation, $r_{s}$, for percent of basin (2500-3000 m elevation) covered by snow on three dates (2000-2009) versus total stream discharge volume from five streams: Bull Lake Creek above Bull Lake, Dinwoody Creek above Lakes, Green River at Warren Bridge, Little Popo Agie River near Lander and Wind River near Dubois. The Spearman's Rank correlation significance of deviation from zero values are shown in parentheses, where the lowest values indicate the most significant correlations. Note that the maximum-monthly discharge correlation values generally explain more of the variation than do the daily or seasonal values.

\begin{tabular}{llll}
\hline Day of year & Daily peak & Maximum monthly & Seasonal total \\
\hline 15 April & $0.1515(0.6760)$ & $0.3090(0.3848)$ & $0.1878(0.6032)$ \\
30 April & $0.8424(0.0022)$ & $0.8909(0.0005)$ & $0.8303(0.0029)$ \\
15 May & $0.7939(0.0060)$ & $0.8424(0.0022)$ & $0.8303(0.0029)$ \\
\hline
\end{tabular}

streamflow (streamflow is the dependent variable). Spearman's Rank correlation may be used when a non-parametric statistical test is indicated (to remove assumptions of a normal distribution). The result is the rank correlation coefficient, $r_{s}$, and the two-sided significance of its deviation from zero where the significance is a value in the interval $[0.0,1.0]$, and the lowest values indicate the most significant correlations.

\section{Results and discussion}

\subsection{Snow-cover depletion curves}

MODIS-derived snow-cover depletion curves for 2000-2009 at the three elevation zones in the WRR are shown in Fig. 2A, B and C. There is a great deal of variability from year to year, and no obvious trend in either increasing or decreasing snow cover or change in date of completion of snowmelt in any of the three elevation ranges within the decade of the 2000s.

Rango et al. (1975) developed snow-cover depletion curves using Landsat-1 Multispectral Scanner (MSS) band $5(0.6-0.7 \mu \mathrm{m})$ data at elevations above and below $\sim 3000 \mathrm{~m}$ in the Wind River Range. According to their data, snow cover at the lowest elevations (elevations below $3050 \mathrm{~m}$ as reported in their paper) remained late into July in 1973, and into the month of August in 1974. It is unclear, however, how much of the "snow cover" in August was actually permanent snow and ice, or glaciers. Rango et al. (1975) used 18-day repeat Landsat-1 data, whereas we use daily MODIS data.

Though quantitative comparisons are difficult between the Rango et al. (1975) data from the 1970s and the MODIS data in the 2000s, in part because of lack of adequate data, we can make some observations. MODIS data from the CGF snow-cover products show that snow cover melts by approximately the end of June in all 10 years studied at the lowest elevation range 2500-3000 m (Fig. 2C) whereas Rango et al. (1975) show snow cover remaining at least into late July (in 1973 and 1974). This difference in the date of snowmelt completion between the early 1970s and the 2000s may be real or it could be explained partly by the Landsat- 1 MSS resolution which is $\sim 80 \mathrm{~m}$ and much better than the 500-m resolution of the MODIS snow-cover maps, though the 18-

\section{Table 2}

Spearman's Rank correlation, $r_{s}$, for percent of basin (3000-3500 m elevation) covered by snow on three dates (2000-2009) versus total stream discharge volume from five streams: Bull Lake Creek above Bull Lake, Dinwoody Creek above Lakes, Green River at Warren Bridge, Little Popo Agie River near Lander and Wind River near Dubois. The Spearman's Rank correlation significance of deviation from zero values are shown in parentheses, where the lowest values indicate the most significant correlations. Note that the maximum-monthly discharge correlation values generally explain more of the variation than do the daily or seasonal values.

\begin{tabular}{lrrr}
\hline Day of year & \multicolumn{1}{l}{ Daily peak } & Maximum monthly & \multicolumn{1}{c}{ Seasonal total } \\
\hline 15 April & $-0.1878(0.6032)$ & $-0.3090(0.3848)$ & $-0.1757(0.6271)$ \\
30 April & $0.7212(0.0185)$ & $0.8303(0.0029)$ & $0.7090(0.0216)$ \\
15 May & $0.8181(0.00381)$ & $0.7090(0.0216)$ & $0.7939(0.0060)$ \\
\hline
\end{tabular}

Table 3

Spearman's Rank correlation, $r_{s}$, for percent of basin ( $\geq 3500$ m elevation) covered by snow on three dates (2000-2009) versus total stream discharge volume from five streams: Bull Lake Creek above Bull Lake, Dinwoody Creek above Lakes, Green River at Warren Bridge, Little Popo Agie River near Lander and Wind River near Dubois. The Spearman's Rank correlation significance of deviation from zero values are shown in parentheses, where the lowest values indicate the most significant correlations. Note that the maximum-monthly discharge correlation values generally explain more of the variation than do the daily or seasonal values.

\begin{tabular}{llcl}
\hline Day of year & Daily peak & Maximum monthly & Seasonal total \\
\hline 15 April & $0.2521(0.4821)$ & $-0.0323(0.9293)$ & $0.0323(0.9293)$ \\
30 April & $0.3503(0.3209)$ & $0.4930(0.1476)$ & $0.3762(0.2838)$ \\
15 May & $0.5384(0.1083)$ & $0.5449(0.1033)$ & $0.5319(0.1134)$ \\
\hline
\end{tabular}

day repeat of the Landsat- 1 may also be a factor. Also the Rango et al. (1975) data show only two years in the 1970s.

\subsection{Stream discharge}

Fig. 3 shows annual hydrographs for the Wind River near Dubois wherein a decline occurs in stream discharge for each decade from 1970 to 2009. Though nearly all of the basins studied showed the greatest stream discharge in the decade of the 1970s, for the Dinwoody
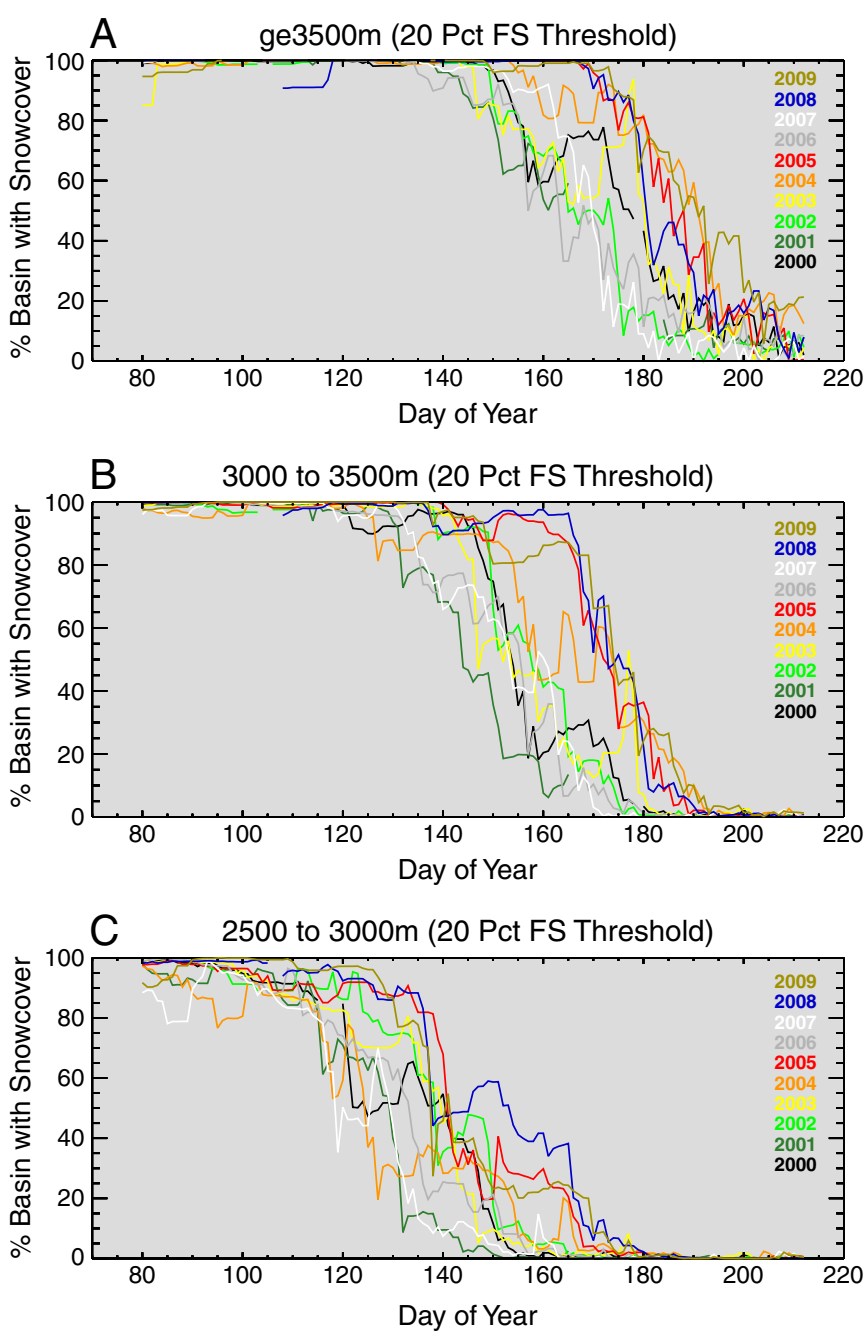

Fig. 2. A, B and C. Snow-cover depletion curves from the MODIS cloud-gap-filled (CGF) 500-m resolution product derived from the fractional snow-cover product, MOD10A1, in the Wind River Range, Wyoming. Breaks are evident in the plots in some years due to sporadic missing MODIS data. (A) Elevation greater than or equal to $3500 \mathrm{~m}$; (B) elevation from 3000 to $3500 \mathrm{~m}$; (C) elevation from 2500 to $3000 \mathrm{~m}$. 


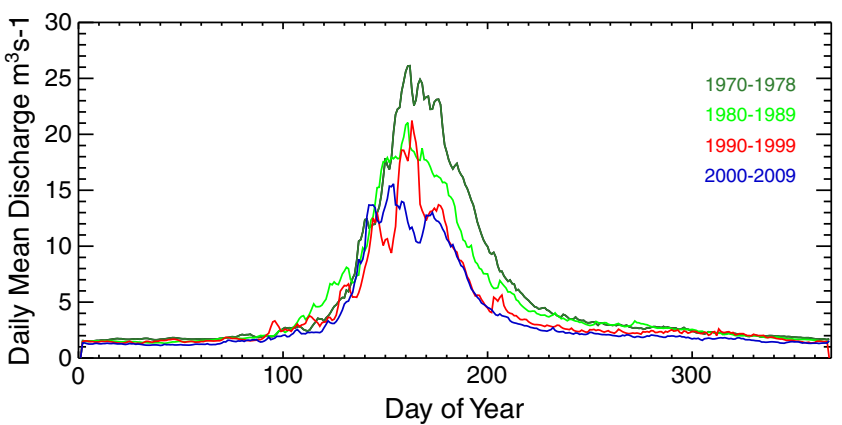

Fig. 3. Annual hydrographs composed of average mean daily flows for each decade from the Wind River near Dubois in the Wind River Range, Wyoming; mean flow values of each day were computed for each decade from daily mean flow data. Data were missing between 1992 and 2001, so the decade of 1990-1999 includes only two years, and the decade of 2000-2009 includes only nine years (discharge data for the Wind River near Dubois for the decade of the 2000s began on 1 May 2001 so data from 2000 are not available).

Creek above Lakes and Bull Lake Creek basins (not shown), discharge decreased noticeably only in the decade of the 2000s as compared to the decade of the 1970s. Also of note, the date of peak discharge is earlier in the 2000s as compared to the previous decades in the discharge data of the Wind River near Dubois shown in Fig. 3.

Using Spearman's Rank correlation analysis, we correlated percent of basin that was snow covered on three dates (15 April, 30 April and 15 May) versus: 1) volume of daily peak streamflow; 2) volume of maximum monthly streamflow; and 3) volume of seasonal total streamflow (Tables 1-3). In all cases, we add the streamflow total volume of five streams studied to derive Tables 1-3. For the lowestelevation zone (2500-3000 m), the highest $r_{s}$ was found when percent of basin that was snow covered on 30 April in each year (Table 1) was correlated with maximum monthly streamflow, meaning that maximum monthly streamflow can be predicted if the percent of the basin that is snow covered on 30 April in a given year is known (Fig. 4). This information is useful for hydrologists who need to predict streamflow for management of reservoirs, based on snowcover observations on a given date prior to completion of snowmelt.

The correlations between percent of basin covered by snow and streamflow are much lower in the mid-range (3000-3500 $\mathrm{m}$ ) and the highest $(\geq 3500 \mathrm{~m})$ elevation zones of the WRR. Since the stream gauges are located within or below the lowest-elevation zone (2500$3000 \mathrm{~m}$ ), the strongest correlations are to be expected there.

\subsection{Stream power}

The ability of a stream to erode the stream bed is dependent in part upon the slope of the bed and the particle size of the sediment load.

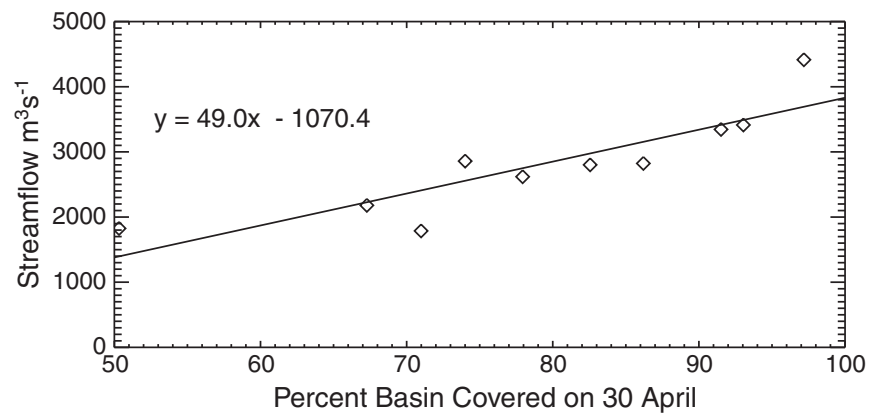

Fig. 4. Regression relationship from which amount of (volume) stream discharge can be predicted if the percent basin coverage is known on 30 April for the lowest elevation zone (2500-3000 m) of our study area in the Wind River Range. This relationship is based on 10 years of MODIS cloud-gap-filled (CGF) snow-cover data and stream discharge data (2000-2009). Spearman's Rank correlation, $\mathrm{r}_{\mathrm{s}}$, for this relationship is 0.89 .

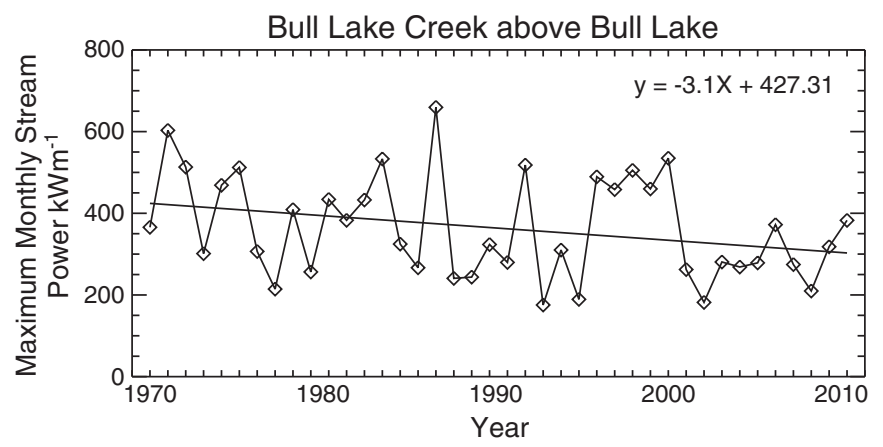

Fig. 5. Stream power per unit length for Bull Lake Creek above Bull Lake is plotted for the 40-year study period (1970-2009). The trend toward decreasing stream power is significant at the $90 \%$ confidence level using a two-tailed $T$-test.

Most of the erosion work is done by a river or stream during peakflow conditions. Fig. 5 shows the maximum monthly stream power of Bull Lake Creek above Bull Lake from 1970 to 2009. A decrease occurs in amount of stream power over the 40 -year period that is significant at the $90 \%$ confidence level. This apparent decreasing trend in stream power is not surprising because we observed a decrease in meanannual daily discharge from 1970 to 2009 (see Fig. 3 as an example).

\subsection{Relationship of streamflow and stream power to air temperature}

To investigate whether the observed decade-scale decreases in discharge, stream power and changes in the timing of snowmelt at the lowest elevation range over the last four decades are related to air temperature trends, we plotted weekly mean minimum and weekly mean maximum air temperature from five meteorological stations in Wyoming near the WRR. Table 4 shows the trend data for the five stations, with statistical significance calculated using a two-tailed Tdistribution at the 95 and 99\% confidence levels. Fig. 6 shows results from the station at Pinedale as an example. For the decade of the 1970 s, an increase is seen in weekly mean maximum $\left(4.36^{\circ} \mathrm{C}\right.$ per decade) and weekly mean minimum $\left(1.93^{\circ} \mathrm{C}\right.$ per decade) air temperature at Pinedale; weekly mean maximum increases are also notable in the 1970 s at Dubois and Jackson (Table 4). Within the decades of the 1980s and 2000s, there are no trends (significant at the $95 \%$ confidence level or higher) in air temperature. Looking at the $40-$ year period from 1970 to 2009 as a whole, however, air temperature data at three of the five stations studied show increases (at the $95 \%$ or greater confidence level) from 1970 to 2009 (Table 4).

\subsection{Further discussion}

When the extent of snow cover is used in concert with hydrological modeling (see for example, Rango and Martinec, 1979; Lee et al.,

Table 4

Weekly-mean minimum and weekly mean-maximum air temperature trends $\left({ }^{\circ} \mathrm{C}\right)$ per decade for five stations in and near the Wind River Range, Wyoming, 1970-2009. Trends that are statistically significant (at the $95 \%$ confidence level or higher) using a two-tailed $T$-test, are shown in bold.

\begin{tabular}{lrrlrr}
\hline & Dubois & Jackson & Lander Hunt & Pinedale & Riverton \\
\hline 1970s min & -1.00 & -1.82 & 0.02 & 1.93 & 0.09 \\
1970s max & $\mathbf{4 . 7 5}^{*}$ & $\mathbf{3 . 5 5}$ & 1.13 & $\mathbf{4 . 3 6}$ & -1.36 \\
1980s min & 2.04 & -1.67 & 0.88 & -0.16 & -0.92 \\
1980s max & 0.75 & 0.96 & 1.10 & -0.39 & 2.14 \\
1990s min & 0.86 & $\mathbf{2 . 5 7}$ & 0.30 & 1.08 & $\mathbf{4 . 6 9}^{*}$ \\
1990s max & 0.40 & 0.97 & 0.37 & -1.23 & 2.75 \\
2000s min & 0.06 & 0.15 & 0.20 & -0.43 & 1.66 \\
2000s max & 0.00 & -0.31 & 0.44 & -1.84 & 1.02 \\
1970-2009 min & $\mathbf{0 . 3 3}$ & $\mathbf{0 . 4 6}$ & 0.34 & 0.33 & $\mathbf{0 . 9 0}^{*}$ \\
1970-2009 max & 0.01 & $\mathbf{0 . 5 3}$ & 0.37 & -0.14 & $\mathbf{0 . 4 7}^{*}$ \\
\hline
\end{tabular}

* Significant at the $99 \%$ level. 

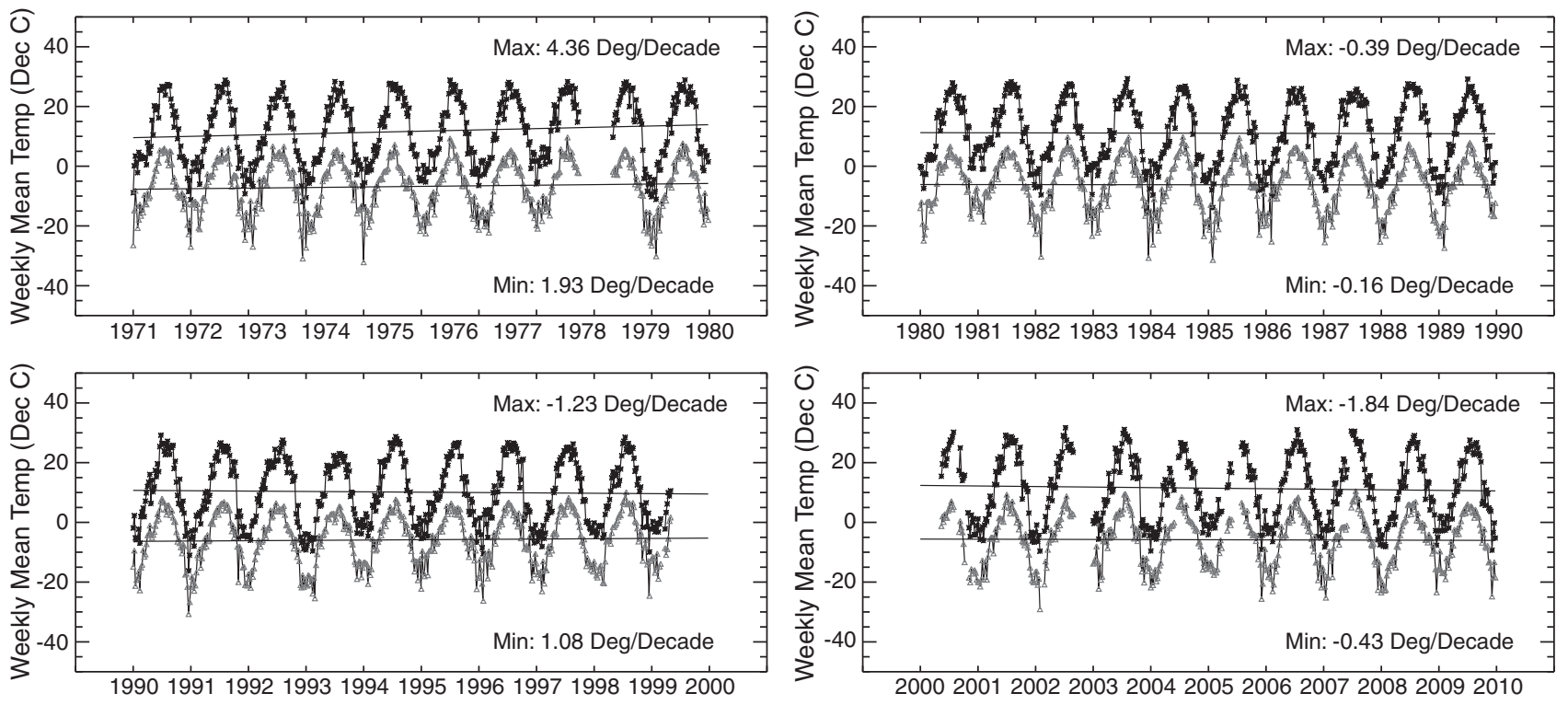

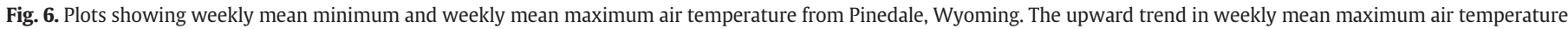

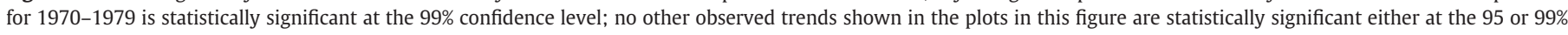
confidence levels.

2005; Tekeli et al., 2005; Zhou et al., 2005; Parajka and Blöschl, 2008), the ability to forecast stream discharge is possible. Knowledge of the magnitude of discharge from both gauged and ungauged basins is needed to forecast streamflow on all basins to improve waterresources planning. We have demonstrated that MODIS CGF snowcover maps can be used for predicting stream discharge. Once a relationship is established between the extent of snow cover and discharge on gauged basins, stream discharge can be predicted on nearby ungauged basins.

\section{Conclusions}

The extent of snow cover extent derived from the lowest elevation range (2500-3000 $\mathrm{m}$ ) of the WRR using CGF snow-cover maps is strongly correlated with the maximum monthly discharge on 30 April of each year, where $r_{s}=0.89$ (Table 1 ).

There is a reduction of stream power from 1970 to 2009 on Bull Lake Creek above Bull Lake (Fig. 5). If this trend (significant at the 90\% confidence level) continues, the stream will be increasingly less effective in eroding its bed.

Air temperature data at three of the five stations studied show statistically-significant increases (at the $95 \%$ or greater confidence level) from 1970 to 2009, though statistically-significant increases were not found within the decade of the 1980s or the 2000s. A notable decrease in discharge occurred in all streams studied for which adequate data were available, in the decade of the 2000s as compared to the three previous decades. For the Wind River near Dubois, for example, stream discharge is shown to decrease each decade, from 1970 to 2009 and the average date of peak mean daily discharge is earlier in the 2000s than in the previous three decades. Additionally, satellite-derived evidence suggests that complete snowmelt occurred later below $3000 \mathrm{~m}$ in 1973 and 1974 as compared to the decade of the 2000s based on comparisons with an earlier investigation (Rango et al., 1975) that used Landsat data to map snow-cover extent and snowmelt timing.

Our data show quite a bit of variability in snow cover, air temperature, streamflow and stream power during the decade of the 2000s, though there is no obvious trend in either the date of melt onset, or the date of peak mean daily discharge as determined from
MODIS-derived snow-cover depletion curves, and discharge data of the three elevation ranges of the WRR that we studied. Nor were there statistically-significant increases in air temperature observed at any of the five meteorological stations that we studied, within the decade of the 2000s.

Percentage of basin-wide snow cover and timing of snowmelt are primary drivers of discharge in the snow-dominated WRR. Therefore, it is important to understand the complex relationship between snow cover and streamflow, and snow cover and stream power, in the context of trends in air temperature and/or climate change. Such information can be used to improve management of the scarce water resources in the drought-prone western United States.

\section{Acknowledgments}

The authors thank Dr. Dan Cayan/University of California San Diego and USGS and Dr. Kelly Redmond/Desert Research Institute for discussions about snow extent and snowmelt-timing trends in the western United States. We also thank Dr. Jonathan Barton, NASA/GSFC and Oak Ridge Associated Universities, for providing insightful ideas and information on stream power, and for his review of the paper. Dr. Allan James, the Guest Editor, provided additional valuable suggestions. Finally we thank the two anonymous reviewers for their constructive comments. This work is supported by NASA's Earth Observing System Program.

\section{References}

Bagnold, R.A., 1977. Bedload transport by natural rivers. Water Resources Research 13, 303-312.

Bloom, A., 1991. Geomorphology: a systematic analysis of late Cenozoic landforms. Prentice Hall, Englewood Cliffs, New Jersey, pp. 236-237.

Cayan, D.R., Kammerdiener, S.A., Dettinger, M.D., Caprio, J.M., Peterson, D.H., 2001 Changes in the onset of spring in the western United States. Bulletin of the American Meteorological Society 82 (3), 399-415. doi:10.1175/1520-0477(2001) 082<0399: CITOOS $>2.3 . C 0 ; 2$.

Cheesbrough, K., Edmunds, J., Tootle, G., Kerr, G., Pochop, L., 2009. Estimated Wind River Range (Wyoming, USA) glacier melt water contributions to agriculture. Remote Sensing 1, 818-828. doi:10.3390/rs1040818.

Cohen, J., Fletcher, C., 2007. Improved skill for northern hemisphere winter surface temperature predictions based on land-atmosphere fall anomalies. Journal of Climate 20, 4118-4132. 
Crowder, D.W., Knapp, H.V., 2005. Effective discharge recurrence intervals of Illinois streams. Geomorphology 64, 167-184.

Dettinger, M.D., Cayan, D.R., 1995. Large-scale atmospheric forcing of recent trends toward early snowmelt runoff in California. Journal of Climate 8, 606-623.

Ferguson, R.I., 2005. Estimating critical stream power for bedload transport calculations in gravel-bed rivers. Geomorphology 70, 33-41.

Foster, J.L., Hall, D.K., 1981. Multisensor analysis of hydrologic features with emphasis on the Seasat SAR. Photogrammetric Engineering and Remote Sensing 47 (5), 655-664.

Foster, J.L., Owe, M., Rango, A., 1983. Snow cover and temperature relationships in North America and Eurasia. Journal of Climate and Applied Meteorology 22 (3), 460-469.

Groisman, P.Ya., Karl, T.R., Knight, R.W., 1994. Changes of snow cover, temperature, and radiative heat balance over the northern hemisphere. Journal of Climate 7, 1633-1656.

Hall, D.K., Riggs, G.A., 2007. Accuracy assessment of the MODIS snow-cover products. Hydrological Processes 21, 1534-1547.

Hall, D.K., Riggs, G.A., Salomonson, V.V., DiGirolamo, N.E., Bayr, K.J., 2002. MODIS snowcover products. Remote Sensing of Environment 83 (1-2), 181-194.

Hall, D.K., Riggs, G.A., Foster, J.L., Kumar, S.V., 2010. Development and evaluation of a cloud-gap-filled MODIS daily snow-cover product. Remote Sensing of Environment $114,496-503$.

JPL, http://www2.jpl.nasa.gov/srtm/cbanddataproducts.htm [accessed on 21 May 2010].

Karl, T.R., Jones, P.D., et al., 1993. A new perspective on recent global warming: asymmetric trends of daily maximum and minimum temperature. Bulletin of the American Meteorological Society 74 (6), 997-1006.

Klein, A.G., Stroeve, J., 2002. Development and validation of a snow albedo algorithm for the MODIS instrument. Annals of Glaciology 34, 45-52.

Lee, S., Klein, A.G., Over, T.M., 2005. A comparison of MODIS and NOHRSC snow-cover products for simulating streamflow using the snowmelt runoff model. Hydrological Processes 19, 2951-2972. doi:10.1002/hyp. 5810.

Lundquist, J.D., Dettinger, M.D., Stewart, I.T., Cayan, D.R., 2009. Variability and trends in spring runoff in the western United States. In: Wagner, F. (Ed.), Climate warming in western North America - Evidence and Environmental Effects. University of Utah Press, pp. 63-76.

Meier, M., 1950. Glaciers of the Gannett Peak - Fremont Peak Area, Wyoming. Graduate Thesis, Department of Geology: University of Iowa.

MODIS, a. http://modis.gsfc.nasa.gov [accessed on 21 May 2010].

MODIS, b. http://modis-snow-ice.gsfc.nasa.gov/sug c5.pdf [accessed on 21 May 2010]

Moore, R.D., Fleming, S.W., Menounos, B., Wheate, R., Fountain, A., Stahl, K., Holm, K., Jakob, M., 2009. Glacier change in western North America: influences on hydrology, geomorphic hazards and water quality. Hydrological Processes 23, 42-61. doi:10.1002/hyp.7162.

Mote, P.W., 2003. Trends in snow water equivalent in the Pacific Northwest and their climatic causes. Geophysical Research Letters 30. doi:10.1029/2003GL017258.

Mote, P.W., Hamlet, A.F., Clark, M.P., Lettenmaier, D.P., 2005. Declining mountain snowpack in western North America. Bulletin of the American Meteorologica Society. doi:10.1175/BAMS-86-1-39 (Jan.).
Naftz, D.L., Susong, D.D., Schuster, P.F., Cecil, L.D., Dettinger, M.D., Michel, R.L., Kendall, C., 2002. Ice core evidence of rapid air temperature increases since 1960 in alpine areas of the Wind River Range, Wyoming, United States. Journal of Geophysical Research 107 (D13). doi:10.1029/2001JD000621.

NCDC, http://cdo.ncdc.noaa.gov/pls/plclimprod/poemain.accessrouter?datasetabbv=SOD [accessed on 21 May 2010].

Oswald, E.B., Wohl, E., 2008. Wood-mediated geomorphic effects of a jökulhlaup in the Wind River Mountains, Wyoming. Geomorphology 100 (3-4), 549-562. doi:10.1016/j.geomorph.2008.02.002.

Parajka, J., Blöschl, G., 2008. The value of MODIS snow cover data in validating and calibrating conceptual hydrologic models. Journal of Hydrology 358, 240-258.

PDX, a. http://glaciers.research.pdx.edu/ [accessed on 21 May 2010].

PDX, b. http://glaciers.research.pdx.edu/glaciers-wyoming [accessed on 21 May 2010].

Pochop, L., Marston, R., Kerr, G., Varuska, M., 1989. Long-term trends in glacier and snowmelt runoff Wind River Range, Wyoming. Wyoming Water Research Center, University of Wyoming, Laramie, Wyoming.

Pochop, L., Marston, R., Kerr, G., Veryzer, D., Varuska, M., Jacobel, R., 1990. Glacial Icemelt in the Wind River Range, Wyoming. Watershed Planning and Analysis in Action Symposium, Proceedings of IR Conference. American Society of Civil Engineers. WWRC-90-16.

Rango, A., Martinec, J., 1979. Application of a snowmelt-runoff model using Landsat data. Nordic Hydrology 10, 225-238.

Rango, A., Salomonson, V.V., Foster, J.L., 1975. Employment of satellite snowcover observations for improving seasonal runoff estimates. In: Rango, A. (Ed.), Operational Applications of Satellite Snowcover Observations: A Workshop held in South Lake Tahoe, Calif., 18-20 August, 1975, pp. 157-174.

Riggs, G.A., Hall, D.K., Salomonson, V.V., 2006. MODIS snow products user guide. http:// modis-snow-ice.gsfc.nasa.gov/sug_c5.pdf.

Salomonson, V.V., Appel, I., 2004. Estimating the fractional snow cover using the normalized difference snow index. Remote Sensing of Environment 89 (3), 351-360.

Stewart, I.T., Cayan, D.R., Dettinger, M.D., 2005. Changes toward earlier streamflow timing across western North America. Journal of Climate 18, 1136-1155.

Tekeli, A.E., Akyurek, Z., Sorman, A.A., Sensoy, A., Sorman, A.U., 2005. Using MODIS snow cover maps in modeling snowmelt runoff process in the eastern part of Turkey. Remote Sensing of Environment 97, 216-230.

USGS, 2005. Changes in Streamflow Timing in the Western United States in Recent Decades. U.S. Geological Survey Fact Sheet 2005-3018.

USGS, http://waterdata.usgs.gov/wy/nwis/ [accessed on 21 May 2010].

Westerling, A.L., Hidalgo, H.G., Cayan, D.R., Swetnam, T.W., 2006. Warming and earlier spring increase western U.S. forest wildfire activity. Science 313, 940-943. doi:10.1126/science.1128834.

Zhou, X., Xie, H., Hendrickx, J.M.H., 2005. Statistical evaluation of remotely sensed snow-cover products with constraints from streamflow and SNOTEL measurements. Remote Sensing of Environment 94, 214-231. 